\title{
Crossed control revisited \\ The structure and interpretations of "want" and so on + passive verb in Malay/Indonesian
}

\author{
HIROKI NOMOTO
}

\begin{abstract}
In Malay/Indonesian, when certain predicates such as "want" are followed by a passive verb, an ambiguity arises about who has the desire and other attitudes in question. The attitude-holder can be either the surface subject or the passive agent. This article critically assesses the data and claims presented in three recent studies (Mike Berger 2019; Paul Kroeger and Kristen Frazier 2020; Helen Jeoung 2020) through consideration of additional data. It shows that the ambiguity is empirically robust, contrary to the doubts expressed by Jeoung, and that the restructuring analysis advocated by the latter two studies has problems with its primary evidence: alternate voice marking realization. Instead, the article confirms the previous understanding of the construction, including a bi-clausal structure with a dyadic matrix predicate and the importance of voice marking. Methodologically, it demonstrates that linguistic evidence should come from multiple sources, that is, not from elicitation or texts alone but from both of these (and perhaps more).
\end{abstract}

KEYWORDS

Indonesian; crossed control; voice; verb-auxiliary distinction; restructuring.

HIROKI NOMOTO is an associate professor of Malay language and linguistics at Tokyo University of Foreign Studies. His areas of research are syntax, semantics, and language resource development in Malay/Indonesian. He has developed two important resources: the morphological dictionary MALINDO Morph and the concordancer MALINDO Conc, both of which are publicly available online. Hiroki Nomoto can be contacted at: nomoto@tufs.ac.jp. 


\section{INTRODUCTION ${ }^{1}$}

In Malay/Indonesian, when certain predicates such as "want" are followed by a passive verb phrase as in (1), an ambiguity arises with regard to who has the desire and other relevant attitudes in question. The attitude-holder can be either the surface subject (non-crossed reading) or the passive agent (crossed reading).

\section{(1) Kucing=nya ma(h)u/suka di-cium oleh Siti. ${ }^{2}$ cat=3 want/like PASS-kiss by Siti}

(i) 'Her cat wants/likes to be kissed by Siti.'

(non-crossed reading; attitude-holder $=$ her cat)

(ii) 'Siti wants/likes to kiss her cat.'

(crossed reading; attitude-holder $=$ Siti $)$

The crossed reading is referred as such because, in order to find the attitude-holder of the matrix predicate, one needs to pass through the embedded subject position (between ma(h)u/suka and dicium in (1)), which is associated with the internal argument of the embedded passive verb ("kisser" in (1)). This can be depicted as in (2) (see Section 2 for more details).

(2) Crossed reading: 'Siti wants/likes to kiss her cat.'

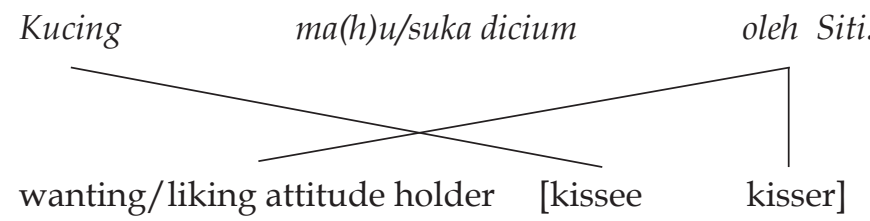

In her recent article that appeared in Language, Jeoung (2020) casts doubt on the empirical robustness of the crossed reading of Indonesian predicates such as mau 'want' and suka 'like'. Jeoung suggests that the crossed reading is not as common as previously thought and that what has been analysed as such in fact involves a different meaning, more specifically an aspectual meaning of the same predicate: 'about to, will' for mau and 'often' for suka. That is to say, the ambiguity found in sentences like (1) is no more than a commonplace lexical ambiguity and hence does not require any special syntactic or semantic

1 This work was supported by JSPS KAKENHI Grant Number JP18K00568. I would like to thank Dian Annisa Nur Ridha, Thathit Puspaning Gegana, Sri Budi Lestari, Shabrina Hazimi Putri, Hilda Amalia, Livie Olivia, Friska Ganiaputri, and David Moeljadi for their help with Indonesian examples. I would also like to thank Helen Jeoung, Paul Kroeger, Yuta Sakon, and the volume editors for their comments and suggestions on earlier versions of this article. Needless to say, all errors are solely mine.

${ }^{2}$ I do not provide glosses for all morphemes but only for inflectional affixes/reduplications and clitics. For example, -nya is glossed when it is a third person enlitic, but not when it is an adverbial deriving suffix as in biasanya 'normally' (< biasa 'normal'). Reduplication is glossed as PL when it is a plural (as opposed to singular and general) number marking (Hiroki Nomoto 2013), but not when it serves other functions as in apa-apa 'anything' (<apa 'what'). 
treatment. Since the aspectual meaning has generally been recognized in the literature, sentence (1) is three-way ambiguous, with the third meaning (iii) 'Her cat is \{about to be/often\} kissed by Siti.' By contrast, if the crossed reading turns out to be an aspectual reading, it is only two-way ambiguous between (i) and (iii), with (iii) often mistaken as (ii).

Jeoung (2020) further claims that the relevant predicates are also ambiguous in terms of syntactic categories. Mau and other similar predicates are verbs when they convey attitudinal meanings (for example, 'want', 'like') but auxiliaries (which include negation, modals, tense, and aspect markers in Jeoung's definition) when they convey temporal meanings (for example, 'about to, will', 'often'). ${ }^{3}$ The distinction between verbs and auxiliaries has also been brought up in the discussion of sentences like (1) by Kroeger and Frazier (2020). Contrary to Jeoung (2020), they propose a new diagnostic and argue that mau and similar predicates are verbs in the attitudinal meanings as well. Another recent study by Berger (2019) proposes a restructuring analysis of the crossed reading, whereby the two verbs in a sentence share a single voice feature and consequently a bi-clausal sentence behaves like a mono-clausal one.

In this article, I assess the data and claims put forward in these recent developments. I make extensive use of the Indonesian sub-corpora of MALINDO Conc (Hiroki Nomoto, Shiro Akasegawa, and Asako Shiohara 2018a). ${ }^{4}$ They consist of the rearranged version of the Leipzig Corpora Collection (Dirk Goldhahn, Thomas Eckart, and Uwe Quasthoff 2012; Nomoto, Akasegawa, and Shiohara 2018b) and the Indonesian Frog Storytelling Corpus (David Moeljadi 2014). These two corpora are composed of 900,000 sentences (14,470,873 words) and 755 sentences (22,446 words), respectively. There are at least two advantages in using MALINDO Conc. Firstly, it has a morphological search function to facilitate searching for specific syntactic patterns. For example, one can search the corpora with a query such as (3), which returns sentences containing mau or suka immediately followed by a word prefixed by di-.

(3) a. Keyword

Surface Form $=$ mau $\mid$ suka

b. Collocate

(i) Find Collocate between R1 and R1

(ii) Prefix $=$ di-

Secondly, one can estimate the replicability of the descriptive generalizations reported in the literature. We tend to think that a fact reported about a language

${ }^{3}$ Jeoung refers to these two readings as "verbal" and "auxiliary" readings. I have not adopted these terms here to avoid unwanted confusion between meanings and syntactic categories. Although strong associations do exist between attitudinal meanings and verbs, as well as between temporal meanings and auxiliaries, such meaning-syntactic category associations do not always hold true either intra- or cross-linguistically.

${ }^{4}$ See https://malindo.aa-ken.jp/conc/. 
applies to most, if not all, speakers of the language. However, this is actually not always the case. For instance, if a study is based solely on elicitation, the reported facts are definitely correct insofar as the couple of individuals who were interviewed are concerned, but nothing guarantees that these facts extend to other speakers. A sufficiently large collection of texts with a known size helps to understand to what extent they are shared by other speakers in the speech community.

The rest of the article is organized as follows. Section 2 gives an overview of the construction and examines the community-level validity of Jeoung's first claim above: what has been thought of as a crossed reading is in fact an aspectual reading. It will be shown that the crossed reading exists alongside the aspectual reading. Section 3 discusses whether the construction is monoclausal or bi-clausal, more specifically, whether predicates like mau and suka are auxiliaries or not. I conclude that the construction is bi-clausal. The section also discusses the restructuring analysis. It will be pointed out that the idea of alternate realization of a shared voice feature, which lies at the core of the restructuring analysis, fails to gain sufficient empirical support. Section 4 is the conclusion, in which I draw attention to two matters that will play a major role in future study of the phenomenon, namely the status of the bare active voice and the mechanism responsible for the ambiguity. I discuss Indonesian data in this article because the previous studies with which I have been concerned discuss it. However, what I claim here should also apply to Standard Malay used in Malaysia, Brunei, and Singapore.

\section{CROSSED READING}

\subsection{BASIC FACTS ABOUT THE CONSTRUCTION}

The construction involving the kind of ambiguity as shown in (1) lacks a good name. David Gil (2002) has named it "funny control", as one of its potential interpretations sounds funny in normal contexts. For instance, the non-crossed reading in (4) sounds funny because thieves do not wish to get caught in normal contexts.

(4) Pencuri itu mau di-tangkap polisi. thief that want PASS-catch police

(i) 'The thief wanted to be caught by the police.' (non-crossed reading)

(ii) 'The police wanted to catch the thief.' (crossed reading)

In recent years, the construction has more commonly been referred to as the crossed control construction, after its crossed reading. Neither name is accurate, however. This is because the construction, at least in its crossed reading, does not involve control (Nomoto 2011). For this reason, I do not call the two interpretations "normal control" and "crossed control" readings.

Besides mau and suka, Nomoto (2011) lists in (5) the following predicates (in Malay) as among those that behave similarly. 
(5) berani 'brave', berjaya 'succeed', berhak 'have the right to', berhasil 'succeed', berusaha 'make effort', cuba (coba in Indonesian) 'try', enggan 'reluctant', gagal 'fail', hendak/nak 'want', ingin 'want', layak 'qualified', mahu/mau 'want', malas 'lazy', malu 'ashamed', mampu 'capable', rela 'willing', sempat 'have time', suka 'like', takut 'afraid', terpaksa 'forced'

Hiroki Nomoto and Kartini Abd. Wahab (2011) add kena 'pressed by external circumstances' (in Malay), and Kroeger and Frazier (2020) add nekat 'insist', lupa 'forget', and tolak 'refuse' to this list. ${ }^{5}$

In terms of syntax, the construction is characterized by two elements. The first element is a dyadic matrix predicate ("funny predicate", "crossed control predicate"). Its first argument denotes an attitude-holder (experiencer) and the other the proposition/situation of which the relevant attitude is spoken. In this respect, the construction resembles control. The second element is a passive verb phrase describing the proposition. If the embedded verb bears the active voice marker $m e N-$, the crossed reading disappears, which indicates that the construction involves an A-movement (Nomoto 2011). The surface subject originates from the embedded clause. Therefore, the construction is not control but more like raising, at least in its crossed reading. (6) shows three key points in the derivation of sentence (4) above.

(6) a. $\left[_{\text {VoiceP }}\left[{ }_{D P}\right.\right.$ pencuri itu $]$ ditangkap polisi $]$
b. $\left[_{\mathrm{VP}}\right.$ mau $\left[_{\mathrm{VoiceP}}[\mathrm{DP}\right.$ pencuri itu $]$ ditangkap polisi $]$
(merger of matrix $\mathrm{V}$ )
c. $\left[_{\mathrm{DP}}\right.$ pencuri itu $]\left[_{\mathrm{VP}}\right.$ mau $\left[_{\mathrm{VoiceP}} t_{\mathrm{DP}}\right.$ ditangkap polis $\left.]\right]$
(DP movement)

It is a matter of debate whether the non-crossed reading also arises from this structure or whether it arises only from a standard control structure as in (7) (see Section 4 for more details).

(7) $\left[_{\mathrm{DP}}\right.$ pencuri itu $]\left[_{\mathrm{VP}} \operatorname{mau}\left[_{\mathrm{CP}}\left[_{\mathrm{TP}} \mathrm{PRO}\left[_{\mathrm{VoiceP}} t_{\mathrm{PRO}}\right.\right.\right.\right.$ ditangkap polisi $\left.\left.\left.]\right]\right]\right]$

In addition to the morphological passive with the prefix di-found in the examples so far, Indonesian has another type of passive, as illustrated in (8).

(8) Buku ini tidak akan kami baca.

book this not will 1PL read

'The book will not be read by us.'

(James Neil Sneddon et al. 2010: 258)

This kind of passive is variously referred to as bare passive, passive type 2, pasif semu, zero passive, or object(ive) voice. Bare passives are found in many languages in Nusantara. They differ from morphological passives in that the verb appears in its bare stem form, with no overt voice marker. Furthermore, the agent occurs adjacent to the verb, a property shared by morphological passive sentences without the "by" agentive preposition, as in (4), but not

\footnotetext{
${ }^{5}$ Kena in Indonesian differs from kena in Malay and should not be included in the list (Nomoto and Kartini 2012).
} 
any active sentences. ${ }^{6}$ In addition to these defining properties, Indonesian imposes the following language-specific restrictions on the agent: (i) it must be overt, (ii) it must precede the verb, and (iii) it must be a pronoun or pronoun substitute (Sneddon et al. 2010: 257). The first two restrictions are common in languages that have bare passives, but the third one is not (Nomoto 2021).

Bare passives can also occur in the crossed control construction, as shown in (9), in which the passive clause is indicated by the brackets.

(9) Beliau tidak mau [saya wawancarai].

3SG not want 1SG interview

(i) 'He doesn't want me to interview him.'

(ii) 'I don't want to interview him.'

(Sneddon et al. 2010: 281)

Semantically, non-crossed and crossed readings differ with regard to which argument of the embedded verb the external argument (EA) (= attitude-holder) of the matrix predicate is identified with. As depicted in (10), the attitudeholder is identified with the internal argument (IA) in the non-crossed reading, whereas it is identified with the external argument in the crossed reading. ${ }^{7}$

(10) a. Non-crossed reading: 'The thief wanted to be caught by the police.'

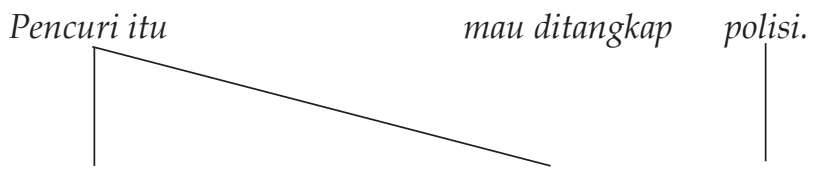

wanting attitude holder [catchee (IA) catcher (EA)]

b. Crossed reading: 'The police wanted to catch the thief.'

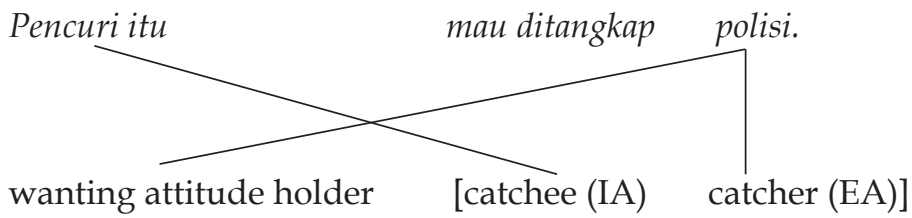

At least two predicates, namely mau and suka, also have a temporal meaning: 'about to, will' and 'often', respectively.

\footnotetext{
a. Mau hujan rupanya.

about.to rain looks.like

'Looks like it's going to rain very soon.'
}

${ }^{6}$ See Nomoto (2020) for the evidence that the post-adjacent DP (polisi in (4)) is an argument, like the bare passive agent.

${ }^{7}$ I assume that passive clauses are transitive. The external argument is present in the structure as a null pronoun when it does not appear overtly. This null pronoun can be semantically identified with the noun phrase introduced by an agentive preposition such as oleh 'by' (see (1)) (Nomoto 2016). 
b. Pensil semacam ini suka patah. pencil like this often break 'Pencils like this often break.'

(KBBI 2016)

Crucially, these verbs are not dyadic but monadic when they express a temporal meaning; the matrix predicate only takes a verb phrase denoting the situation it modifies, but not a noun phrase denoting individuals. (12) depicts the third, temporal interpretation of sentence (4). Notice that the line indicating the attitude-holder in (10) is absent in (12).

(12) Temporal reading: 'The thief was about to be caught by the police.'

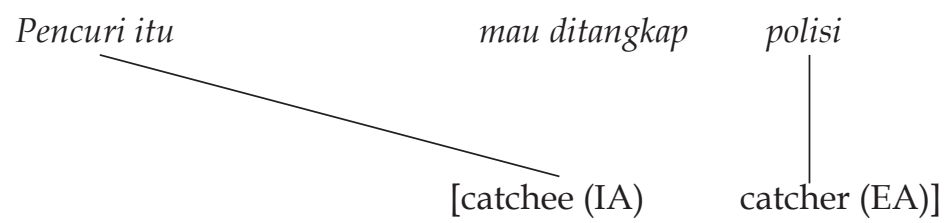

\subsection{DOES THE CROSSED READING REALLY EXIST?}

Jeoung (2020) doubts the existence of the crossed reading. She suggests that what has been taken as a crossed reading is in fact a temporal reading. To explore this possibility, I examined the Indonesian corpora in MALINDO Conc. Firstly, I collected sentences in which mau and suka are followed by a passive verb phrase. For di- passives, I used MALINDO Conc's morphological search, by which one can restrict the word immediately after mau/suka to those prefixed by di-. For bare passives, I picked out relevant sentences manually.

Next, I examined the interpretation of each sentence. Teasing apart the crossed and temporal interpretations was often difficult, even after inspecting the surrounding discourse context. This difficulty is also noted by Jeoung (2020: footnote 13). Hence, I made categories like "crossed or temporal", "crossed > temporal", and "temporal > crossed".

\subsubsection{Mau}

\section{$M a u+d i$ - passive}

Since the results were numerous (475 sentences), I only looked at those in which the agent is overtly expressed, either as a post-adjacent DP, as in (4), or in an oleh 'by' PP, as in (1). I found fifty such sentences. ${ }^{8}$ The interpretations of these sentences are summarized in Table 1.

\footnotetext{
${ }^{8}$ Some sentences occur in more than one sub-corpus. I removed such duplicates by hand.
} 


\begin{tabular}{lc}
\hline \multicolumn{1}{c}{ Interpretation } & Frequency \\
\hline non-crossed & 34 \\
crossed & 6 \\
temporal & 2 \\
crossed or temporal & 7 \\
unclear & 1 \\
\hline Total & 50 \\
\hline
\end{tabular}

Table 1. Interpretations of "mau $+d i$ - passive" sentences.

(13) is one of the six sentences I classified as a "crossed" reading. The context after this sentence shows that he likes the clothes very much. Hence, it is more plausible to interpret this mau as 'want' or 'intend' rather than a pure temporal marker.
Baju=nya yang di-pake tidur tidak mau di-ganti=nya. clothes $=3$ REL PASS-wear sleep not MAU PASS-change $=3$

'He didn't want to change his clothes which he wore when sleeping. ${ }^{9}$

The context surrounding sentence (13) is given in (14). Incidentally, (14) contains as many as five instances of mau. The second and fourth instances are followed by a passive verb phrase, whereas the other three are followed by an active verb phrase. In my interpretation, all instances convey desire or intention, although the fourth instance could be purely temporal.

(14) Waktu menunjukkan pukul 06.50. eh, ternyata Ridwan tak mau ganti baju. Bajunya yang dipake tidur tidak ${ }_{(2)}$ mau digantinya. Baju 48 bermotif mobil traktor dengan saku di depan itu terlihat kumal. Tapi Ridwan tetap tak ${ }_{(3)}$ mau ganti baju. Bahkan sampai menangis ketika bajunya ${ }_{(4)}$ mau dilepas. Karena takut terlambat ke kantor, maka biarlah Ridwan tidak mandi dan tak ${ }_{(5)}$ mau ganti baju.

'The time pointed to 6.50. Eh, it turned out Ridwan did not ${ }_{(1)}$ want to change his clothes. He did not ${ }_{(2)}$ want to change the clothes which he wore when sleeping. The 48 shirt with a picture of a tractor and a pocket on the front looked rumpled. But Ridwan still did not ${ }_{(3)}$ want to change the clothes. In fact, he even cried when someone ${ }_{(4)}$ wanted was about to take off his clothes. Because I feared being late for work, I just let Ridwan not bathe and not (5) want to change clothes. ${ }^{\prime 10}$

(15) is another example in which mau is clearly not temporal but conveys desire/intention. It is unlikely that the reason for not being included in the candidates for the Scarlett O'Hara actress is because Goddard was not about to explain her marriage. Rather, it is more logical to think the reason has to

9 LCC, IND MXD2010, http://andika21.wordpress.com/. Hereafter, the sources of the examples from the Leipzig Corpora Collection will be shown in this way: LCC, Sub-corpus name, URL.

${ }^{10}$ See http:/ / andika21.wordpress.com/; accessed on 1-10-2020. 
do with her general disinclination to do so, regardless of how soon the action was expected to actually happen.

(15) Status pernikahan dengan Chaplin yang tidakmau di-jelaskan Goddard status marriage with Chaplin REL not MAU PASS-explain Goddard mem-buat nama=nya di-coret dari calon pemeran Scarlett ACT-make name $=3$ PASS-delete from candidate role Scarlett

O'Hara untuk film Gone with the Wind.

O'Hara for film Gone with the Wind

'Her marital status with Chaplin, which Goddard did not want to explain, meant her name was removed from the candidates for the role of Scarlett $\mathrm{O}^{\prime}$ Hara in the film Gone with the Wind. ${ }^{\prime 1}$

(16) is one of the seven sentences which I was not able to classify into either "crossed" or "temporal".

(16) Setelah installan kedua ini, memory card internal gakakan mau di-baca after install both this memory card internal not will MAU PASS-read oleh PC, tapi jangan khawatir, cukup di-reboot saja. by PC but don't worry enough PASS-reboot just

'After installing both these, the PC will not \{want to/very soon\} read the internal memory card, but don't worry, you can just reboot your PC. ${ }^{12}$

One may think that mau in (16) is not temporal because the akan 'will' preceding it already indicates time. However, the possibility remains that mau contributes a temporal meaning different from that of akan, which I translated as 'very soon' above.

Incidentally, Jeoung (2020: e169) states that previous accounts of crossed control predict incorrectly that neither non-crossed nor crossed readings are possible with two inanimate arguments, as in (17).

(17) Dalam foto, terlihat mobil yang mau di-tabrak oleh kereta.

in photo seen car REL MAU PASS-crash by train

(i) 'In the photo, there is a car which wants to be hit by a train.'

(non-crossed reading)

(ii) 'In the photo, there is a car which a train wants to hit.'13

(crossed reading)

Jeoung claims that the actual interpretations are not those in (17) but those with the temporal mau: (i) 'In the photo, there is a car which is about to be hit by a train' and (ii) 'In the photo, there is a car which a train is about to hit.'14

${ }^{11}$ LCC, IND WKP2016, http://id.wikipedia.org/wiki/Charlie_Chaplin.

${ }^{12}$ LCC, IND MXD2012, http:/ / alman-nkri.blogspot.com/2010/08/smartphone-samsunggalaxy-s.html.

${ }^{13}$ Jeoung's original: 'In the photo, there is a train that wants to hit a car.'

${ }^{14}$ Jeoung's original: 'In the photo, there is a train that is about to hit a car.' 
However, I would argue that the attitudinal interpretations are also possible in cases where sentences such as (16) and (17) are used figuratively and, strictly speaking, inanimate arguments are treated as if they were animate. Inanimate nouns denoting moving objects, especially large vehicles, often behave like animates (for example, in children's books). In Japanese, for example, animate and inanimate arguments take different existential verbs, namely iru (18a) and aru (18b). Cars and trains take the former, as shown in (18c), unless they are no longer used for transport.
a. Eki ni takusan hito-ga $\left\{i r u /{ }^{*} a r u\right\}$. station at many person-NOM are
'There are many people in the station.'
b. Eki ni takusan jihanki-ga $\quad$ *iru/aru\}. station at many vending.machine-NOM are
'There are many vending machines in the station.'
c. Eki ni takusan kuruma/densha-ga $\left\{\right.$ iru ${ }^{*}$ aru $\}$. station at many car/train-NOM are
'There are many trains in the station.'

Therefore, although it is true that mau can be interpreted temporally, Jeoung's example poses no problem to previous accounts of crossed control.

\section{Mau + bare passive}

Table 2 summarizes the interpretations of mau when followed by a bare passive verb phrase. In contrast to mau followed by a di- passive clause, no instance was found for the non-crossed reading. This is arguably because almost all surface subjects in the sentences of this pattern were inanimate.

\begin{tabular}{lc}
\hline Interpretation & Frequency \\
\hline non-crossed & 0 \\
crossed & 4 \\
crossed $>$ temporal & 22 \\
temporal & 0 \\
temporal $>$ crossed & 5 \\
crossed or temporal & 3 \\
\hline total & 34 \\
\hline
\end{tabular}

Table 2. Interpretations of "mau + bare passive" sentences.

(19) is one of the four sentences that clearly has a crossed reading, expressing the desire/intention of the bare passive agent. Censorship is the act of eliminating words that authorities do not want people to hear or see, but not words they are not about to hear or see. 
(19) Usaha penyensoran ini, juga tercerminkan di dalam adegan di mana effort censorship this also be.reflected at inside scene at where si kakek men-[t]ulis suratke stasiun televisi di mana ia the grandfather ACT-write letter to station television at where 3SG meny-[s]enaraikan kata-kata yang tidak mau ia dengar lagi di televisi. ACT-list word.PL REL not MAU 3SG hear more at television 'This attempt at censorship is reflected in a scene in which the grandfather writes a letter to the TV station, in which he lists words he does not want to hear again on TV.'15

(20) is an example which I classified as "crossed > temporal". The author and his friend Teguh were in Bali and were thinking about how to return to Yogyakarta in Java on their motorcycles. Then, Teguh came up with a good idea, namely to hitch a lift in a lorry returning to Java. Mau here can be interpreted as expressing either his desire/intention or the temporal closeness to the relevant event. The surrounding context reveals that they had not even begun to find the cargo terminal. Although temporal closeness depends on the speaker's perspective (for example, three hours can count as "very soon" in some situation for some people, but not for others), the desire/intention reading sounds more natural here.

(20) Motor mau dia naikin ke atas truk dari Jawa dan ikut motorcycle MAU 3SG put.on to top lorry from Java and together men-[t]umpang.

ACT-ride

'He \{wanted to/was about to $\}$ put his motorcycle on a lorry from Java and hitch a ride. ${ }^{\prime 16}$

Temporal closeness is clearer in (21), though a desire/intention meaning still remains plausible. Therefore, I have classified (21) as "temporal > crossed".

(21) Sayadi-hantui perasaan bersalah, dunia narkotik sudah mau saya 1SG PASS-haunt feeling guilty world drug already MAU 1SG tinggalin.

leave

'I was haunted by a sense of guilt, (so) I already \{was about to/wanted to\} leave the drug scene.' 17

\footnotetext{
${ }^{15}$ LCC, IND WKP2016, http:/ / id.wikipedia.org/wiki/Bart_the_General.

${ }^{16}$ LCC, IND WEB2012, http:/ / arfen-arfen.blogspot.com/.

${ }^{17}$ LCC, IND MXD2012, http:/ / ainuamri.wordpress.com/2010/05/15/terapi-islami-mengatasikecanduan-narkoba/.
} 


\subsubsection{Suka}

\section{Suka + di- passive}

The sentences in which suka is followed by di- passive verb phrases were much fewer than the cases with mau above. Hence, I examined all examples, regardless of whether the passive agent occurs overtly. Table 3 shows the results.

\begin{tabular}{lc}
\hline \multicolumn{1}{c}{ Interpretation } & Frequency \\
\hline non-crossed & 41 \\
crossed & 0 \\
temporal & 3 \\
crossed or temporal & 3 \\
\hline Total & 47 \\
\hline
\end{tabular}

Table 3. Interpretations of "suka $+d i$ - passive" sentences.

For suka, I found no indisputable case of crossed reading for two possible reasons. First, the number of potential examples of crossed and temporal readings is quite small, with the majority of examples being non-crossed reading ones. Second, if a person likes to do something, s/he normally does it often, giving rise to the possibility of a temporal reading. The three examples which I have classified as "crossed or temporal" are given in (22)-(24). In (24), the agent of the passive verb diletakkan 'to be put' is implicit, and the surface subject boneka-boneka 'dolls' occurs postverbally.

(22) Orang sukses me-miliki kebiasaan me-lakukan hal yang tidaksuka person successful ACT-own habit ACT-do thing REL not SUKA di-lakukanoleh orang malas.

PASS-do by person lazy

(i) 'Successful people have the habit of doing things which lazy people do not like to do.' (crossed reading)

(ii) 'Successful people have the habit of doing things which are often not done by lazy people.'18 (temporal reading)

(23) Saya sangat meng-idolakan Scott, dan sakit hati sekali rasanya kalau saya tidak 1SG very ACT-idolize Scot and hurt heart very feel if 1SG not bisa pergi ke tempat-tempat yang suka di-datangi=nya [...]. can go to place.PL REL SUKA PASS-visit=3

(i) 'I idolized Scott a lot, and I felt upset if I couldn't go to the places which he liked to visit.' (crossed reading)

(ii) 'I idolized Scott a lot, and I felt upset if I couldn't go to the places that were often visited by him. ${ }^{19}$ (temporal reading) 
(24) Kalau anak-anak yang meninggal di bawah umur 16 tahun, di makam=nya top child.PL REL pass.away at below age 16 year at grave $=3$

suka di-letakkan boneka-boneka gitu, [...].

SUKA PASS-put doll.PL like.that

(i) 'In the case of children who have passed away under the age of 16, (people) like to put dolls at their graves.' (crossed reading)

(ii) 'In the case of children who have passed away under the age of 16, dolls are often put at their graves.' ${ }^{20}$

(temporal reading)

\section{Suka + bare passive}

Only three sentences which have this pattern were found. (25) and (26) have a crossed reading. In (25), suka cannot mean 'often' because it is semantically incompatible with kadang-kadang 'sometimes' preceding it. A temporal meaning ('things which are not often done by you') also arises in (26), but it is an implicature; you are not likely to often do things which you can do only by disciplining yourself.

(25) Yang aku syukuri tuh, dia selama ini masih jujur (kadang ${ }^{2}$ REL 1SG thank PART 3SG during this still honest sometimes suka aku uji)".

SUKA 1SG test

'What I'm grateful for is, she (= the author's maid) has been honest so far (sometimes I like testing that). ${ }^{21}$

(26) Kadang kamu harus men-disiplinkan diri untuk me-lakukan sometimes 2 must ACT-discipline self to ACT-do

hal-hal yang tidak suka kamu lakukan, [...].

thing.PL REL not SUKA 2 do

'Sometimes you must discipline yourself to do things that you do not like to do.'22

From my understanding, suka in (27) also has a crossed reading, although the possibility of a temporal reading remains.

${ }^{20}$ LCC, IND WEB2012, http:/ / articlewithnoidentity.blogspot.com/2009_06_01_archive.html.

${ }^{21}$ LCC, IND WEB2012, http://anakku-tercinta.blogspot.com/2008_12_01_archive.html.

${ }^{22}$ LCC, IND WEB2012, http:/ / agustlahab.blogspot.com/. 
(27) Kalau kita perhatikan pola makan orang barat, bobot bahan if 1PL observe pattern eat person west weight material

makanan yang suka mereka konsumsi, dari tahun ke tahun

food REL SUKA 3PL consume from year to year

makin lama makin meningkat.

increasingly long increasingly rise

'If we observe the dietary pattern of Westerners, the portion of the food which they like to consume grows bigger year by year.' ${ }^{23}$

To summarize, corpus examples suggest that, at the speech community level, both mau and suka have a distinct crossed reading alongside the temporal reading.

\section{Clause structure}

In the previous section, I examined possible interpretations of sentences with mau/suka followed by a passive verb phrase. What emerges is that the crossed reading exists alongside the temporal reading and cannot be replaced with the latter. An independent issue is the syntactic category of mau, suka, and similar predicates (crossed control predicates). When she suggests that what has been thought of as a crossed reading "could result from misunderstanding or overlooking an auxiliary interpretation [= temporal reading-HN]" (Jeoung 2020: e167), Jeoung (2020) assumes that crossed control predicates are auxiliaries in temporal reading (for example, 'about to, will', 'often'), but they are verbs in non-crossed reading (for example, 'want', 'like'). Although we no longer need to worry about temporal reading, it is important to determine whether crossed reading arises from a bi-clausal structure, in which the crossed control predicate is a verb which takes a verb phrase as its complement, as schematically shown in (28a), but not a mono-clausal structure, as shown in (28b).

(28) a. Bi-clausal structure

Theme $\left[_{\mathrm{VP}}\right.$ mau/suka $\left[_{\mathrm{Voice}}\right.$ Agent $\left.\left.\mathrm{v}_{\text {pass }}\left[_{\mathrm{VP}} \mathrm{V} t_{\text {Theme }}\right]\right]\right]$

b. Mono-clausal structure

Theme $\left[_{\text {AuxP }}\right.$ mau/suka $\left[_{\text {VoiceP }}\right.$ Agent $\left.\left.\mathrm{v}_{\text {pass }}\left[{ }_{\mathrm{VP}} \mathrm{V} t_{\text {Theme }}\right]\right]\right]$

If the sentence giving rise to the crossed reading has a mono-clausal structure, the interpretive mechanism involved is essentially the same as that of subject-oriented adverbs and root modals. They can be associated with either the surface subject or the passive verb agent ("logical subject"), corresponding to the non-crossed and crossed readings. In (29), for example, the individual who is careful and who is under an obligation can be either John or the doctor. 
(29) a. John was carefully examined by the doctor. (Ray Jackendoff 1972: 83)

b. John must be examined by the doctor.

Indeed, some previous authors have ascribed crossed reading to the auxiliary status of mau and other words meaning "want" (Isamu Shoho 1995; Shin Fukuda 2007; Simon Musgrave 2001; Hirobumi R. Sato 2004). For mau, the authoritative dictionary Kamus Besar Bahasa Indonesia (KBBI) lists its intention/desire meaning as adverbia, which includes auxiliaries as well as adverbs. ${ }^{24}$ George Quinn's The learner's dictionary of today's Indonesian (Quinn 1999) also regards mau followed by a verb phrase as an auxiliary. If these descriptions are correct, mau is not an ideal predicate with which to investigate the phenomenon, and we should look at other predicates such as coba 'try'.

Crossed control is considered to be special because the type of ambiguity found in (29) arises from a bi-clausal, control-like structure. Therefore, it is important to ensure that the construction in question is bi-clausal, but not mono-clausal. However, as can be seen in (28), the two structures are very similar. The surface similarity is illustrated in (30), adapted from Kroeger and Frazier (2020). (30a) contains auxiliaries and is mono-clausal, whereas (30b) contains crossed control predicates and is bi-clausal.

(30) a. Ayah sudah/telah/akan ku=obati.

father already/PFV/will $15 G=$ treat(medically)

'I \{already treated/have treated/will treat\} father.'

b. Ayah coba/mau/suka ku=obati.

father try/want/like 1SG=treat(medically)

'I try/want/like to treat father.'

The following two facts in (30a) and (30b) that Nomoto (2011) points out make distinguishing between the two structures even more difficult.

(31) a. No volce MORPHOLOGY

Crossed control predicates either contain no affix at all or are prefixed by ber- or ter-. They never take the active voice prefix meN-.

b. Modal SEMAntics

The meaning of crossed control predicates pertains to either psychological attitudes or external circumstances which affect the realization of a situation.

These characteristics also apply to auxiliaries, with the exception of the derivational prefixes ber- and ter-.

In their discussion of kena 'pressed by external circumstances' in Malay, Nomoto and Kartini (2011) propose a fronting test to distinguish between auxiliaries and crossed control predicates. When multiple auxiliaries occur in a passive clause, they are fronted together, as shown in (32). This is not

\footnotetext{
${ }^{24}$ Surprisingly, KBBI's entry of mau does not have any verb usage.
} 
possible for the combination of sudah 'already' and cuba 'try' (Malay equivalent of coba), indicating that coba is not an auxiliary.
a. Sudah boleh=kah rumah itu di-jual? already $\operatorname{can}=\mathrm{Q}$ house that PASS-sell 'Can the house now be sold?'
b. *Sudah cuba=kah rumah itu___ di-jual? already try $=\mathrm{Q}$ house that PASS-sell
c. Rumah itu sudah cubadi-jual. house that already try PASS-sell '(Someone) has already tried to sell the house.'

(Nomoto and Kartini 2011: 374)

Nomoto and Kartini (2011) state that (32b) is ungrammatical because sudah and cuba do not form a constituent. However, this explanation leads one to make a wrong prediction, namely that the generalization about fronting also holds with active clauses, contrary to the fact (Ramli Haji Salleh 1995: 104). Although the reason for the contrast is unclear, the test is still useful. The same contrast is observed in the following Indonesian examples.
a. Sudah pernah=kah Tono di-dekati Sabrina? already have $=\mathrm{Q} \quad$ Tono PASS-approach Sabrina 'Has Tono already been approached by Sabrina?'
b. *Sudah coba=kah Tono di-dekati Sabrina? already try $=\mathrm{Q}$ Tono PASS-approach Sabrina
c. Tono sudah coba di-dekati Sabrina. Tono already try PASS-approach Sabrina
(i) 'Tono has already tried to be approached by Sabrina.' (non-crossed reading)
(ii) 'Sabrina has already tried to approach Tono.'
(crossed reading)

Kroeger and Frazier (2020), inspired by the conference presentation which was later published as Jeoung 2020, propose another diagnostic which differentiates crossed control predicates from auxiliaries: crossed control predicates can be passivized, whereas auxiliaries cannot be. They present the examples in (34) and (35) as support. In their analysis, the parts in boldface in (35) are in the bare passive. 
(34) Di-passive

a. Buah itu kemudian di-coba di-makan, ternyata rasa=nya fruit that subsequently PASS-try PASS-eat perceived flavor=3 asam. sour

'The fruit was then tried to be eaten, and its taste was found to be sour.'25

b. Tapi kitatak tahu apa yang di-suka makan ... but 1PL not know what REL PASS-like eat

'But we don't know what they like to eat ... ${ }^{\prime 26}$

(35) Bare passive

a. Makanan terburuk yang pernah saya coba makan. food worst REL PRF 1SG try eat

'The worst food that I have ever tried to eat.' (literally, 'that has ever tried to be eaten by me.' $)^{27}$

b. Sekadar bergambar bersama durian yang tidak $k u=s u k a$ makan. enough pictured with durian REL not 1SG=like eat (photo caption) 'Barely able to be photographed with durian, which I do not like to eat.' (literally, 'which does not like to be eaten by me.') (28 $^{28}$

Kroeger and Frazier's diagnostic predicts that (30a) cannot be passivized, whereas $(30 b)$ can be. I asked eight Indonesian speakers for acceptability judgements. ${ }^{29}$ The predicted contrast was not found. The number in the brackets following the sentence shows the number of speakers who judged the sentence to be "absolutely unnatural, incorrect". No sentence was judged as "absolutely natural" by any speaker. Furthermore, MALINDO Conc, which contains some 900,000 Indonesian sentences, did not have any examples containing dicoba/dimau/disuka obati (37a) and kucoba/kumau/kusuka obati (37b). ${ }^{30}$ Therefore, Kroeger and Frazier's diagnostic is unreliable from a practical point of view.

${ }^{25}$ See http:/ / surabaya.tribunnews.com/2010/09/21/olah-bogem-menjadi-sirup-dodol-danselai.

${ }^{26}$ See http:/ / abdrahims.blogspot.com/2013/02/kenal.html.

${ }^{27}$ See https://www.tripadvisor.co.id/Restaurant_Review-g187849-d2356409-ReviewsMarcellino_Pane_e_Vino-Milan_Lombardy.html.

${ }^{28}$ See http:/ / oxygen94.blogspot.com/2012/01/.

${ }^{29}$ Seven speakers are from Java (west, central, and east), and one is from Sumatra.

${ }^{30}$ A Google search (conducted on 8-11-2020) returned eight distinct sentences containing dicoba obati. This presents the methodological question of how large our corpus should be to show that a particular pattern is common in a language. 
a. *Ayah di-sudah/di-telah/di-akan obati oleh ibu. [7/8] father PASS-already/PASS-PFV/PASS-will treat(medically) by mother

('Mother \{already treated/have treated/will treat\} father.')

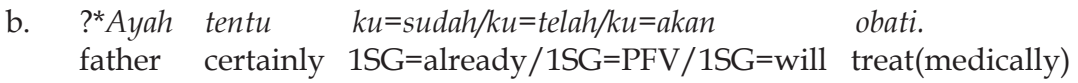

('I certainly \{already treated/have treated/will treat\} father.') (36b)
a. ?*Ayah di-coba/di-mau/di-suka
obati oleh ibu. [4/8]
father PASS-try/PASS-want/PASS-like treat(medically) by mother
('Mother \{already treated/have treated/will treat\} father.')
b. ?*Ayah tentu $\quad k u=$ coba/ku=mau/ku=suka obati.
father certainly $1 S G=$ try $/ 1 S G=$ want/1SG=like treat(medically)
('I certainly try/want/like to treat father.')

It is worthwhile to consider why the prediction was not borne out. First, one of the speakers who judged (36b) as "absolutely unnatural" notes that this type of sentence might be natural in some areas and that she feels that she has heard them in lyrics. I argue that this is because (36b) can be parsed as a bare active sentence with topicalization, as shown in (38).

$$
\left[_{\mathrm{TopP}} \text { Ayah } \mathrm{i}_{\mathrm{i}} \text { tentu }\left[_{\mathrm{TP}} \mathrm{ku}=\left[_{\mathrm{T}^{\prime}} \text { sudah }\left[_{\text {VoiceP }} \text { obati } t_{\mathrm{i}}\right]\right]\right]\right]
$$

It is not difficult to find the pronoun $k u$ in the surface subject position, which seems to be procliticized to the following word or to have undergone shortening.

(39) Sebab ku akan rapuh saat kau jauh.

because 1SG will fragile when 2 far

'Because I will be fragile when you are far away.' ${ }^{31}$

(40) Meski ke tujuh samudera, pasti ku kan men-[t]unggu;karena ku even.if to seven ocean certain 1SG will ACT-wait because 1SG

yakin, kau hanya untuk=ku

confident 2 only for=1SG

'Even if you go across the seven oceans, I'll certainly wait for you; because

I'm confident you are only for me.'

(Kahitna Untukku)

If (36b) is a bare active sentence, (37b) should also have a bare active parsing, as in (41a). However, unlike the former, the latter has a more prominent parsing without topicalization, namely bare passive, as in (41b). ${ }^{32}$ However, this structure is ungrammatical because the lower VoiceP lacks an external argument. If the lower VoiceP is in the bare active, the external argument of obati should have raised to the surface subject position which ayah occupies. If it is in the bare passive, the external argument of obati should have remained in its initially merged position, as in (41c).

${ }^{31}$ LCC, IND WEB2012, http:/ / aliceritapendek.blogspot.com/ .

${ }^{32}$ The adverb tentu 'certainly' is adjoined to VoiceP in this structure. 


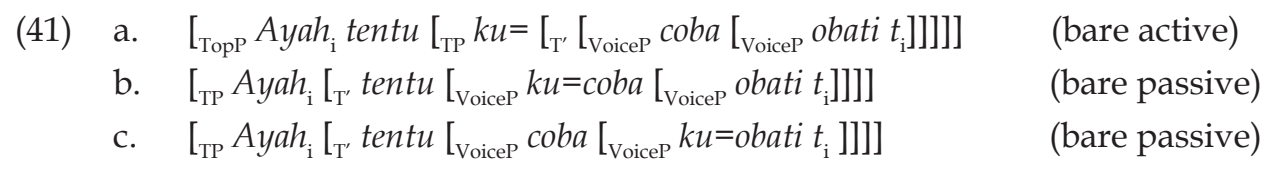

If (41b) is ungrammatical, why do sentences like (35), which Kroeger and Frazier (2020) present as bare passive, exist in the first place? One possible reason is speaker variability. However, I believe that another possibility is more likely. Auxiliary/negation (Aux/Neg) fronting from a bare active clause occurs for informational structural reasons. Because Aux/Neg is a syntactic head as opposed to a phrase, it is possible for it to undergo head movement. Informally speaking, the fronted Aux/Neg is given emphasis, unlike the non-fronted Aux/Neg in bare passives. Under this "bare active + fronting" analysis, (35) involves the structures shown in (42), in which the external argument of makan is relativized, and in which the auxiliary pernah and the negation tidak moves to the focus head above TP.

$$
\begin{aligned}
& \text { a. makanan terburuk yang }\left[_{\mathrm{FocP}} \underset{\uparrow}{\text { pernah }}\left[_{\mathrm{TP}} \text { saya }\left[_{\mathrm{T}^{\prime}}\left[\left[_{\mathrm{VoiceP}} \quad \text { coba makan }\right]\right]\right]\right]\right. \\
& \text { b. [...] durian yang [ }\left[_{\mathrm{FocP}} \operatorname{tidak}\left[\left[_{\mathrm{TP}} k u\left[_{\mathrm{T}^{\prime}}\left[_{\mathrm{VoiceP}}-\text { suka makan }\right]\right]\right]\right]\right.
\end{aligned}
$$

Aux/Neg fronting is not limited to bare active clauses. In (43)-(44) below, fronting occurs from morphological active clauses with the prefix meN-.

(43) Bagaimana bisa kita__meng-ajak seseorang yang takut air berenang how can 1PL ACT-invite someone REL afraid water swim bersama? together

'How can we invite someone who is afraid of water to swim with us?' 33

(44) Tidak pernah mereka ___ mem-[p]andang nyanyian sebagai sekadar not have 3PL ACT-see singing as just hiburan saja. entertainment only

'Never have they seen singing just as entertainment.' ${ }^{34}$

Let us next turn to (37a). Berger (2019) and Kroeger and Frazier (2020) report that some speakers allow the passive marker normally occurring with the embedded verb to be realized on the matrix predicate. However, none of my consultants allowed such alternate realization, although two noted that dicoba, but not dimau and disuka, might be used by some speakers. To confirm this remark, one relevant example was found in the corpus. 
(45) Karena itu, Agormen-coba meng-[k]urangi pandangan sendiri terhadap ayat because that Agor ACT-try ACT-reduce view own towards verse yang di-coba pahami.

REL PASS-try understand

'Because of that, I [= Agor] try to reduce my own views on the verses which I try to understand. ${ }^{\prime 35}$

Given the large size of the corpus, it can be said that alternate realization is possible only for a very limited group of speakers. For Berger (2019) as well as Kroeger and Frazier (2020), alternate realization is a crucial evidence to support their claim that the crossed control construction, in fact, involves restructuring, a phenomenon also found in other languages such as Spanish and German. Their evidence seems genuine, but at the same time, it is rather difficult to replicate by means of either elicitation or corpora. However, another way of understanding what appears to be alternate realization exists: coba/mau/ suka and the subsequent bare verb form a compound verb. In this compound verb, the passive prefix is expected to occur to the left of the whole verb stem (coba obati in (45)), without harming the compound's lexical integrity. As compounding is a lexical matter, differences in availability across words and speakers also follow naturally.

Berger (2019) furthermore claims that examples such as (46) exemplify a novel type of restructuring in which a single passive voice feature is realized in two verbs.
Perampok di-coba di-tangkap polisi. thief PASS-try PASS-catch police
(i) ${ }^{*}$ The thief tried to be caught by the police.'
(non-crossed reading)
(ii) 'The police tried to catch the thief.'
(crossed reading)

These types of sentences are common. Examples such as (46) indicate the presence of two distinct voice positions, associated with upper and lower verb phrases, and hence argue for the bi-clausal structure in (28a). However, notice that with the introduction of the passive voice morphology on the crossed control predicate coba, the interesting ambiguity disappears, with only the crossed reading being available. This is unexpected unless one assumes that the normal control reading arises only from a normal control structure. If (46) has the same restructuring structure as (47) does and differs from the latter only in the way in which the passive voice is realized, no difference should exist in terms of possible interpretations. In Berger's analysis, a single instance of passive voice is realized for both upper and lower verbs in (46) but only for the lower verb in (47), with the upper verb being left unmarked for voice. 
(47) Perampok coba di-tangkap polisi.

thief try PASS-catch police

(i) 'The thief tried to be caught by the police.'

(non-crossed reading)

(ii) 'The police tried to catch the thief.'

(crossed reading)

The two di-'s are therefore exponents of two distinct morphemes. The $d i-$ prefixed to the crossed control predicate coba affects the interpretation, just as the active voice prefix meN- does, as in (48).

(48) Perampok itu men-coba di-tangkap polisi.

thief that ACT-try PASS-catch police

(i) 'The thief tried to be caught by the police.' (non-crossed reading)

(ii) *'The police tried to catch the thief.' (crossed reading)

I would analyse sentences such as (46) as a standard bi-clausal structure with a CP complement, paralleling (49) (see Douglas Saddy 1991), in which the referent of the matrix external argument happens to be identical to that of the lower verb.

(49) Perampok itu di-katakan $\left[_{\mathrm{CP}}\right.$ di-tangkap polisi]. thief that PASS-say PASS-catch police

'The thief is said to have been caught by the police.'

In (49), the individual who says that the police caught the thief is normally understood to be someone who is not mentioned in the sentence. However, this is not semantically entailed but rather results from pragmatic inference. Hence, the police can be the relevant individual under certain circumstances. The same mechanism brings about the crossed reading in (46).

Nevertheless, (46) is still important to our discussion. This is because it shows that coba in (47) has an external argument and hence is not a monadic raising predicate but rather a dyadic predicate. By passivizing coba, the external argument ("tryer") can no longer be associated with the surface subject. This does not happen without passivization. Therefore, Nomoto's (2011) morphological generalization about crossed control verbs (31a) can be extended to include the passive prefix $d i$-. Crossed control predicates must occur in the bare active if they are transitive verbs.

To summarize, this section has discussed whether crossed control constructions are mono-clausal or bi-clausal. It has been shown that crossed control constructions are bi-clausal in the sense that crossed control predicates take verb phrases as their complements but are not auxiliaries. Crossed control predicates are not raising predicates either. They are lexically specified as taking two arguments, which means that they have two $\theta$-roles. This section has also discussed recent attempts to reduce crossed control constructions to restructuring. Although the idea is attractive, alternate passive voice realization, which is claimed to cause a bi-clausal structure to function mono-clausally, presents empirical problems. 


\section{CONCLUSION}

After having examined several facts and claims by Berger (2019), Kroeger and Frazier (2020), and Jeoung (2020), my conclusion is that the old view is still valid. The ambiguity between the non-crossed and crossed interpretations is quite robust. Crossed control predicates are not auxiliaries, and hence the construction is bi-clausal. Crossed control predicates are dyadic syntactically as well as semantically. The three studies are valuable because they give us an opportunity to revisit the construction from new perspectives and to pay attention to some of the facts which we have neglected before.

I would also like to draw attention to a point which tends to be neglected, namely the importance of recognizing the bare active voice. ${ }^{36}$ The bare active voice is often considered to be a result of the obligatory or optional omission of the morphological active voice marker $m e N$ - and not a voice of its own. The resulting voice system is either (50a) or (50b). Conversely, I have assumed the system depicted in (50c), following Jan E. Voskuil (2000) and Asmah Hj. Omar (2009), among others. ${ }^{37}$

(50) a.

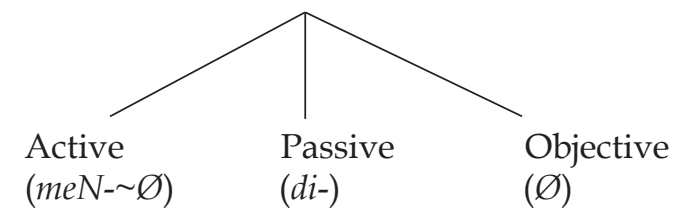

b.

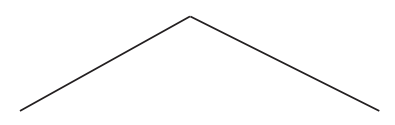

Active $($ meN- $\varnothing)$

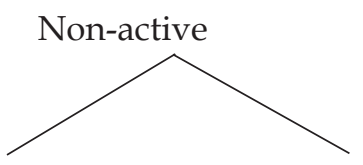

Passive (I)

(di-)

Objective/Passive (II)

$(\varnothing)$

c.

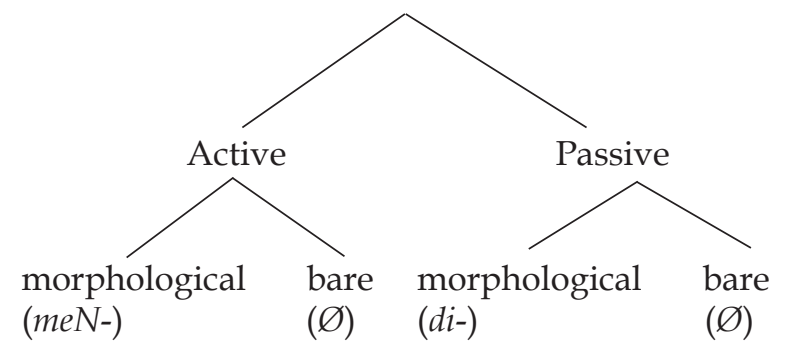

Whether the bare active is a result of omission or not, failure to recognize it can lead to the failure to consider alternative analyses. As seen in the previous section, the surface string " $\mathrm{Aux} / \mathrm{Neg}$ pronoun bare $-\mathrm{V}_{1} \mathrm{~V}_{2}$ " does not necessarily

\footnotetext{
${ }^{36}$ See Sandra Chung (1978) for a convincing argument regarding how bare actives are indeed active and not a variant of bare passives.

${ }^{37}$ The names of the four voices are adopted from Voskuil (2000).
} 
entail that the bare- $\mathrm{V}_{1}$ is in the bare passive. It also arises from a bare active clause through the fronting of Aux/Neg, see (51).

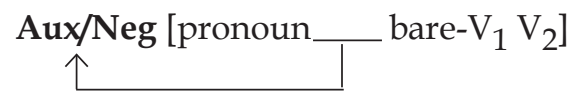

In the same vein, the bare passive structure shown in (52b) is not the only possible analysis of the surface string in (52a). The bare active structure in (52c) is not only possible but also more plausible because $(52 b)$ contains a covert agent, which is ungrammatical in Indonesian.

$$
\begin{aligned}
& \text { a. Mobil manakah yang dia coba curi? } \\
& \text { 'Which car did s/he try to steal?' }
\end{aligned}
$$

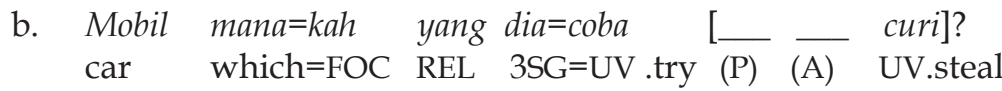

$$
\begin{aligned}
& \text { c. Mobil mana=kah yang dia coba [_curi_ }] \text { ? } \\
& \text { (I Wayan Arka 2014) }
\end{aligned}
$$

Furthermore, we have seen that crossed control predicates which are transitive verbs must be in the bare active, but not the morphological active/passive or the bare passive.

Finally, I must point out that so far, no consensus has been reached about the mechanism responsible for the ambiguity between non-crossed and crossed readings. Some authors propose analyses which derive the two readings from a common structure. Nomoto (2011) and Yosuke Sato (2010) both propose that the two readings are obtained because a point of syntactic derivation exists at which both the surface subject and the passive agent ("logical subject") are accessible for the external $\theta$-role assignment of the crossed control predicate. For Nomoto (2011), the relevant configuration stems from the movement of the theme argument of the passive verb (= surface subject) through the left edge, which the agent also occupies. Sato (2010), who assumes that passive verb phrases lack the left edge employed in Nomoto's analysis, claims that the passive verb moves up to the crossed control predicate. The external $\theta$-role is then assigned either to the surface subject or to the passive prefix $d i$ - $(d i-$ passive) or procliticized agent (bare passive).

By contrast, Berger (2019) explicitly states that the two readings are the result of two distinct structures. The non-crossed reading is obtained from a normal control structure (see (7)) and the crossed reading from a restructuring structure. Maria Polinsky and Eric Potsdom (2008) will also need to appeal to a normal control structure for the non-crossed reading because the latter reading does not arise from the mechanism they propose. They analyse mau/ ingin 'want' as raising verbs, which take only the embedded verb phrase. The identification of the desire-holder is therefore achieved completely through the lexical semantics of mau/ingin. They apply Wyner's analysis of subjectoriented adverbs to mau/ingin, whereby the Proto-Agent in the embedded 
verb, which has a volition property (Adam Zachary Wyner 1998; David Dowty 1991), is semantically identified with the desire-holder. Given that the Proto-Patient does not have a volition property, the Proto-Patient will not be identified with the desire-holder with this mau/ingin. While this can prevent the overgeneration of the unavailable crossed reading when mau/ingin occurs with an active verb phrase, another kind of mau/ingin is necessary to account for the non-crossed reading when mau/ingin occurs with a passive verb phrase.

The language certainly has a normal control structure. It is necessary to account for the non-crossed reading of (48), in which the matrix verb bears the movement blocking prefix meN-. The same structure should be available in general. The question is whether the normal control structure is the only source of the non-crossed reading of the crossed control construction. If it is, the nature of the ambiguity is purely structural. If it also arises from the structure responsible for the crossed reading, the construction also has a semantic property akin to subject-oriented adverbs and root modals in such languages as English (see (29)).

$\begin{array}{ll}\text { ABBREVIATIONS } & \\ 1 & \text { First person } \\ 2 & \text { Second person } \\ 3 & \text { Third person } \\ \text { A } & \text { Agent } \\ \text { ACT } & \text { Active } \\ \text { Aux/Neg } & \text { Auxiliary/Negation } \\ \text { AuxP } & \text { Auxiliary phrase } \\ \text { CP } & \text { Complementizer phrase } \\ \text { DP } & \text { Determiner phrase } \\ \text { EA } & \text { External argument } \\ \text { Foc/FOC } & \text { Focus } \\ \text { Foc' } & \text { Focus phrase (intermediate) } \\ \text { FocP } & \text { Focus phrase } \\ \text { IA } & \text { Internal argument } \\ \text { KBBI } & \text { Kamus Besar Bahasa Indonesia } \\ \text { LCC } & \text { Leipzig Corpora Collection } \\ \text { NOM } & \text { Nominative } \\ \text { P } & \text { Patient } \\ \text { PART } & \text { Particle } \\ \text { PASS } & \text { Passive } \\ \text { PFV } & \text { Perfective } \\ \text { PL } & \text { Plural } \\ \text { PRF } & \text { Perfect } \\ \text { Q } & \text { Question } \\ \text { REL } & \text { Relativizer } \\ \text { SG } & \text { Singular } \\ t & \text { Trace } \\ T^{\prime} & \text { Tense phrase (intermediate) } \\ \text { TOP } & \\ & \end{array}$




$\begin{array}{ll}\text { TopP } & \text { Topic phrase } \\ \text { TP } & \text { Tense phrase } \\ \mathrm{UV} & \text { Undergoer voice } \\ \mathrm{v}_{\text {pass }} & \text { Passive little verb } \\ \mathrm{V} & \text { Verb } \\ \text { VoiceP } & \text { Voice phrase } \\ \text { VP } & \text { Verb phrase }\end{array}$

\section{REFERENCES}

Arka, I Wayan. 2014. “Double and backward control in Indonesian; An LFG analysis", in: Miriam Butt and Tracy Holloway King (eds), Proceedings of the LFG '14 Conference, pp. 26-46. Stanford, CA: CSLI Publications. [URL http://web.stanford.edu/group/cslipublications/ cslipublications/ LFG/19/papers/lfg14arka.pdf.]

Asmah Hj. Omar. 2009. Nahu Melayu mutakhir. Fifth edition. Kuala Lumpur: Dewan Bahasa dan Pustaka.

Berger, Mike. 2019. "Indonesian crossed control; Expanding the typology of restructuring", in: Richard Stockwell, Maura O'Leary, Zhongshi Xu, and Z.L. Zhou (eds), Proceedings of the 36th West Coast Conference on Formal Linguistics, pp. 61-70. Somerville, MA: Cascadilla Proceedings Project. [URL http://www.lingref.com/cpp/wccfl/36/abstract3447.html.]

Chung, Sandra. 1978. "Stem sentences in Indonesian", in: S.A. Wurm and Lois Carrington (eds), Second International Conference on Austronesian Linguistics; Proceedings, pp. 335-365. Canberra: Department of Linguistics, Research School of Pacific Studies, The Australian National University. [Pacific Linguistics Series C 61.]

Dowty, David. 1991. “Thematic proto-roles and argument selection”, Language 67: 547-619. [DOI 10.2307/415037.]

Fukuda, Shin. 2007. “On the control/raising ambiguity with aspectual verbs; A structural account", ZAS Paper 47: 159-195. [URL http://www.zas. gwz-berlin.de/186.html.]

Gil, David. 2002. "The prefixes di- and N- in Malay/Indonesian dialects", in: Fay Wouk and Malcolm Ross (eds), The history and typology of Western Austronesian voice systems, pp. 241-283. Canberra: Pacific Linguistics. [DOI 10.15144/PL-518.241.]

Goldhahn, Dirk, Thomas Eckart, and Uwe Quasthoff. 2012. “Building large monolingual dictionaries at the Leipzig Corpora Collection; From 100 to 200 languages", in: Proceedings of the Eighth International Conference on Language Resources and Evaluation (LREC '12). [URL http:/ / www.lrec-conf. org/proceedings/lrec2012/pdf/327_Paper.pdf.]

Jackendoff, Ray. 1972. Semantic interpretation in generative grammar. Cambridge, MA: MIT Press.

Jeoung, Helen. 2020. “Categorial ambiguity in mau, suka, and other Indonesian predicates", Language 96: e157-e172. [DOI 10.1353/lan.2020.0053.] 
KBBI. 2016. Kamus Besar Bahasa Indonesia. Fifth edition. Jakarta: Badan Pengembangan dan Pembinaan Bahasa.

Kroeger, Paul and Kristen Frazier. 2020. "Crossed-control in Malay/Indonesian as long-distance passivization", in: Ileana Paul (ed.), AFLA 26; Proceedings of the twenty-sixth meeting of the Austronesian Formal Linguistics Association, pp. 159-174. London: University of Western Ontario. [URL https://ir.lib. uwo.ca/afla/aflaxxvi/meeting/10/.]

Moeljadi, David. 2014. "Usage of Indonesian possessive verbal predicates; A statistical analysis based on storytelling survey", Tokyo University Linguistic Papers 35: 155-176.

Musgrave, Simon. 2001. Non-subject arguments in Indonesian. PhD thesis, University of Melbourne. [URL http:/ / hdl.handle.net/11343/38779.]

Nomoto, Hiroki. 2011. "Analisis seragam bagi kawalan lucu", in: Hiroki Nomoto, Zaharani Ahmad, and Anwar Ridhwan (eds), Isamu Shoho; Tinta kenangan "kumpulan esei bahasa dan linguistik", pp. 44-91. Kuala Lumpur: Dewan Bahasa dan Pustaka.

Nomoto, Hiroki. 2013. Number in classifier languages. PhD thesis, University of Minnesota. [URL http://hdl.handle.net/11299/148854.]

Nomoto, Hiroki. 2016. "Passives and clitic doubling; A view from Classical Malay", in: Hiroki Nomoto, Takuya Miyauchi, and Asako Shiohara (eds), AFLA 23; Proceedings of the twenty-third meeting of the Austronesian Formal Linguistics Association, pp. 179-193. Canberra: Asia-Pacific Linguistics.

Nomoto, Hiroki. 2020. "Passive subtypes in Sarawak Malay", in: Thomas J. Conners and Atsuko Utsumi (eds), Aspects of regional varieties of Malay, pp. 139-158. Jakarta/Tokyo: Universitas Katolik Indonesia Atma Jaya and Tokyo University of Foreign Studies. [Volume 68 of NUSA; DOI 10.15026/94897.]

Nomoto, Hiroki. 2021. "Bare passive agent hierarchy", in: Henrison Hsieh and Keely New (eds), AFLA 27; Proceedings of the twenty-seventh meeting of the Austronesian Formal Linguistics Association, pp. 57-70. Ontario: University of Western Ontario.

Nomoto, Hiroki, Shiro Akasegawa, and Asako Shiohara. 2018a. "Building an open online concordancer for Malay/Indonesian". [Paper, the 22nd International Symposium on Malay/Indonesian Linguistics, Los Angeles, 11-12 May; (ISMIL 22).]

Nomoto, Hiroki, Shiro Akasegawa, and Asako Shiohara. 2018b. “Reclassification of the Leipzig Corpora Collection for Malay and Indonesian", NUSA 65: 47-66. [DOI 10.15026/92899.]

Nomoto, Hiroki and Kartini Abd. Wahab. 2011. “Konstruksi kena dalam bahasa Indonesia; Perbandingan dengan bahasa Melayu", Linguistik Indonesia 29:111-131. [URL http:/ / www.tufs.ac.jp/ts/ personal/nomoto/ kena_Indonesia.pdf.]

Nomoto, Hiroki and Kartini Abd. Wahab. 2012. "Kena adversative passives in Malay, funny control, and covert voice alternation", Oceanic Linguistics 51: 360-386. [DOI 10.1353/ ol.2012.0017.] 
Polinsky, Maria and Eric Potsdom. 2008. “The syntax and semantics of wanting in Indonesian", Lingua 118: 1617-1639. [DOI 10.1016/j.lingua.2007.08.005.]

Quinn, George. 1999. The learner's dictionary of today's Indonesian. Canberra: Allen \& Unwin.

Ramli Haji Salleh. 1995. Sintaksis bahasa Melayu; Penerapan teori Kuasaan dan Tambatan. Kuala Lumpur: Dewan Bahasa dan Pustaka.

Saddy, Douglas. 1991. "WH scope mechanism in Bahasa Indonesia", in: Lisa L.S. Cheng and Hamida Demirdash (eds), MIT working papers in linguistics 15; More papers on wh-movement, pp. 183-218. Cambridge, MA: Department of Linguistics and Philosophy, Massachusetts Institute of Technology.

Sato, Hirobumi R. 2004. Kajian semula unsur utama wajib dalam ayat bahasa Melayu. Bandar Seri Begawan: Dewan Bahasa dan Pustaka Brunei.

Sato, Yosuke. 2010. "The crossed-control construction and the syntactic role of passive morphology in Standard Indonesian". [URL http://ling.auf. net/lingbuzz/001177.]

Shoho, Isamu. 1995. "Mareeshiago no IP-kouzou to ninshoukei [I-lowering in Malay focus fronting constructions]", Toukyou Gaikokugo Daigaku Ronshuu 51: 99-117.

Sneddon, James Neil, Alexander K. Adelaar, Dwi N. Djenar, and Michael Ewing. 2010. Indonesian; A comprehensive grammar. Second edition. London: Routledge.

Voskuil, Jan E. 2000. "Indonesian voice and A-bar movement", in: Ileana Paul, Vivianne Phillips, and Lisa Travis (eds), Formal issues in Austronesian linguistics, pp. 195-214. Dordrecht: Kluwer. [Volume 49 of Studies in Natural Language and Linguistic Theory.]

Wyner, Adam Zachary. 1998. "Subject-oriented adverbs are thematically dependent", in: Susan Rothstein (ed.), Events and grammar, pp. 333-348. Dordrecht: Kluwer. 